\title{
A splicing factor that is inactivated during in vivo heat shock is functionally equivalent to the [U4/U6.U5] triple snRNP-specific proteins
}

\author{
Ulrike Utans, ${ }^{1}$ Sven-Erik Behrens, ${ }^{2}$ Reinhard Lührmann, ${ }^{2}$ Ryszard Kole, ${ }^{3}$ and Angela Krämer ${ }^{1,4}$ \\ ${ }^{1}$ Abteilung Zellbiologie, Biozentrum der Universität Basel, CH-4056 Basel, Switzerland; ${ }^{2}$ Institut für Molekularbiologie und \\ Tumorforschung, Universität Marburg, D-3550 Marburg, 27599 Germany; ${ }^{3}$ Department of Pharmacology and Lineberger \\ Cancer Research Center, University of North Carolina, Chapel Hill, North Carolina 27599 USA
}

\begin{abstract}
One of the consequences of the heat shock response is a shutdown of pre-mRNA splicing, a phenomenon that can be reproduced in extracts prepared from heat-shocked cells. The block in splicing occurs before the covalent modifications that generate spliced mRNA at the level of spliceosome formation. We have used extracts prepared from heat-shocked cells as a complementation system to characterize and partially purify a protein factor that is inactivated during the in vivo heat shock. The activity functions in the formation of the active spliceosome by assembling U4/U6 and U5 snRNPs into a triple snRNP particle. The factor appears to be different from previously isolated splicing factors and is functionally equivalent to several polypeptides that are specifically associated with the purified triple snRNP but not with individual U4/U6 or U5 snRNPs. Our data confirm the hypothesis that U4/U6 and U5 snRNPs enter the spliceosome as a triple snRNP complex and show for the first time a function of specific snRNP-associated polypeptides in the mammalian splicing pathway.
\end{abstract}

[Key Words: Pre-mRNA splicing; spliceosome formation; splicing factor; [U4/U6.U5] triple snRNP complex; heat shock response]

Received December 19, 1991; revised version accepted February 13, 1992.

Exposure of cells to stress conditions, such as heat shock, results in the shutdown of the majority of protein synthesis, whereas so-called heat shock proteins (hsp) accumulate. These are believed to protect the cell from injury and ensure recovery after return to normal growth conditions (for references, see Morimoto et al. 1990). The response of cells to stress conditions is in part regulated at the post-transcriptional level by a disruption of the splicing machinery. The majority of the heat-inducible hsp genes do not contain introns; thus, inhibition of premRNA splicing represents a critical point at which the expression of heat shock-inducible and non-hsp transcripts can be regulated differentially. An inhibition of pre-mRNA splicing is also observed in nuclear extracts prepared from heat-shocked mammalian cells (Bond 1988; Shukla et al. 1990). The phenomenon of thermotolerance (i.e., a protection of the splicing apparatus from heat shock after a prior mild heat treatment) observed in vivo can be reproduced in vitro as well (Bond 1988). This implies that the inhibition of splicing seen in extracts from heat-shocked cells reflects the in vivo situation.

\footnotetext{
${ }^{4}$ Corresponding author.
}

Both in vivo and in vitro data suggest that the block in splicing occurs before the covalent modifications that lead to the generation of mature mRNA (Bond 1988; Yost and Lindquist 1988; Shukla et al. 1990). In splicingcompetent extracts the pre-mRNA is spliced by two consecutive cleavage-ligation reactions within large multicomponent complexes or spliceosomes. These structures are asscmbled in a highly ordered pathway that involves the interaction of small nuclear ribonucleoprotein particles (snRNPs) and several protein factors with the substrate RNA (for reviews, see Green 1991; Guthrie 1991). In a first step, $U 1$ and $U 2$ snRNPs bind to the pre-mRNA to form presplicing complex A. U4/U6 and U5 snRNPs join the complex, presumably as a preformed triple snRNP (Bindereif and Green 1987; Cheng and Abelson 1987, Konarska and Sharp 1987), thus generating splicing complex B. A conformational change results in the transition to splicing complex $\mathrm{C}$, which represents the active spliceosome. Within this structure the pre-mRNA is cleaved at the $5^{\prime}$ splice site and concomitantly the $5^{\prime}$ end of the intron is attached to the $2^{\prime}$ hydroxyl group of an adenosine residue in the intron near the $3^{\prime}$ splice site. This results in two reaction intermediates, the $5^{\prime}$ exon and the lariat intron-exon 2 . In the next step the RNA 
is cleaved at the $3^{\prime}$ splice site and the exons are ligated, thus generating the spliced mRNA, as well as the free intron lariat.

The failure of extracts prepared from heat-shocked cells to splice a pre-mRNA substrate can be attributed to a defect in the assembly of the active spliceosome (Bond 1988; Shukla et al. 1990). Depending on the severity of the heat shock, B-complex formation is reduced as well. These effects appear to correlate with a deficiency in the triple snRNP containing U4, U5, and U6 RNAs of the heat shock extract. In addition, Bond (1988) showed that a heat shock at $44^{\circ} \mathrm{C}$ interfered with the integrity of $\mathrm{U} 2$ snRNP and resulted in structural changes in the nonspecific and the presplicing complexes formed in this extract. Shukla et al. (1990) recently demonstrated that the splicing defect after heat shock is caused by the inactivation of a protein factor that was detected in a precipitate obtained after dialysis of splicing-competent extracts against $12.5 \mathrm{mM} \mathrm{MgCl}$ ( $\mathrm{Mg}$ pellet) and was partially purified by column chromatography.

We have investigated whether the complementing activity corresponds to one of the HeLa cell splicing proteins that we have isolated previously (Krämer et al. 1987). We were particularly interested in the question of whether the complementing activity was represented by SF2, which appears to be required for B-complex formation (U. Utans and A. Krämer, unpubl.), or by SF4, which is dispensable for the formation of complex $\mathrm{B}$ and functions in the assembly of the active splicing complex $\mathrm{C}$ and subsequent cleavage and ligation reactions (Utans and Krämer 1990). Splicing factors SF1, SF3, and U2AF, which are essential for the assembly of presplicing complex A (Krämer 1988; Ruskin et al. 1988; Krämer and Utans 1991), are less likely candidates for the complementing activity, as A-complex formation is apparently not perturbed in extracts prepared from cells heatshocked at $43^{\circ} \mathrm{C}$ (Shukla et al. 1990).

Our results suggest that the complementing activity is distinct from previously characterized mammalian splicing factors. The activity functions in the assembly of the [U4/U6.U5] triple snRNP and thus promotes spliceosome formation. Experiments performed with purified snRNPs indicate that the complementing activity is functionally equivalent to one or more of the polypeptides that are specifically associated with the triple snRNP and function in the formation of this particle (Behrens and Lührmann 1991).

\section{Results}

The activity that is inactivated during heat shock is distinct from previously isolated splicing components

In an initial experiment we complemented an extract prepared from heat-shocked cells with fractions enriched in different splicing factors or snRNPs. In our standard fractionation protocol (Krämer et al. 1987) HeLa splicing extracts are subjected to chromatography on DEAESepharose where SF1 activity is recovered in the flowthrough fractions (DS100). Bound components are fractionated further on heparin-Sepharose. SF2 activity is found in the flowthrough (HS100), snRNPs are recovered together with SF3 and SF4 activities in the $0.5 \mathrm{M}$ $\mathrm{KCl}$ step fraction (HS500), and U2AF activity is eluted at $1 \mathrm{M} \mathrm{KCl}$ (HS1000) (Zamore and Green 1989; Krämer and Utans 1991). Chromatography of the HS500 fraction on Mono Q separates SF3 and SF4 activities and individual snRNPs. SF4 activity is purified further by chromatography on Blue-Sepharose (see Materials and methods). (Note that the designation for the splicing factors used in this report differs from that of Krainer and Maniatis (1985). In particular, our SF2 is distinct from SF2 purified by Krainer et al. (1990).]

As shown in Figure 1, the heat shock extract by itself is inactive in splicing the pre-mRNA substrate; splicing activity can be restored to levels observed with regular splicing extract by the addition of the solubilized $\mathrm{Mg}$ pellet (see Shukla et al. 1990). Splicing is not detected when SF1, U2AF, SF2, SF3, or SF4 are added to the heat

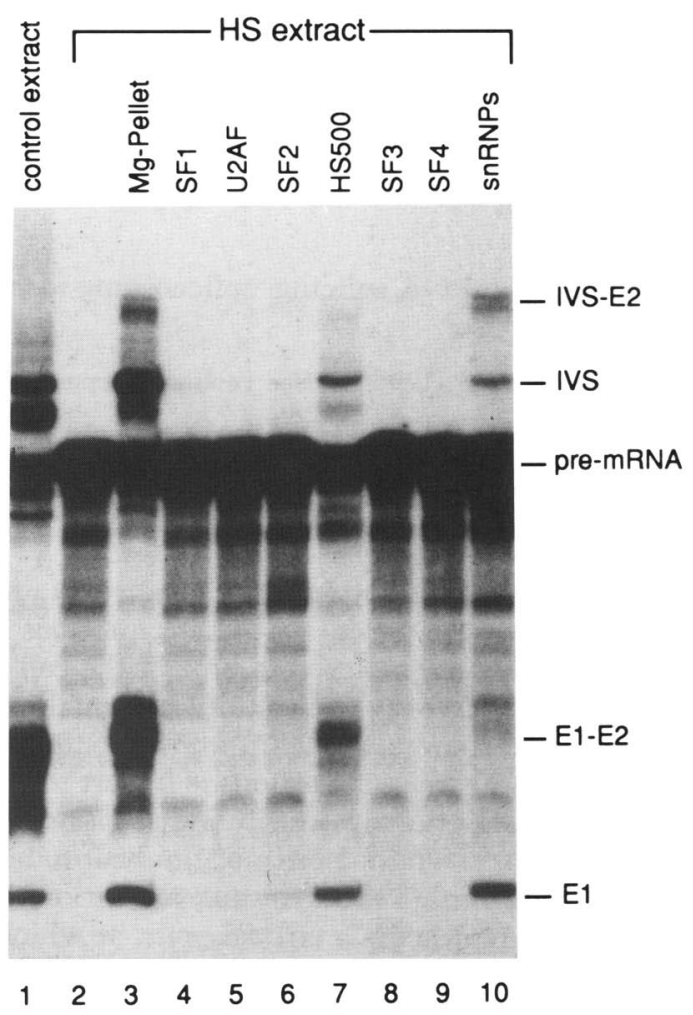

Figure 1. Complementation of heat shock extract with fractionated splicing components. Standard splicing reactions contained (in a total volume of $10 \mu$ l) $3 \mu$ l of heat shock extract (lanes $2-10$ ) and, in addition, $2 \mu \mathrm{l}$ of fractions enriched in the splicing factors indicated above individual lanes. The following fractions were used: (SF1) DS100; (SF2) HS100; (SF3) Mono Q; (SF4) Blue-Sepharose; (U2AF) HS1000; (snRNPs) a 1:1 mixture of Mono Q fractions enriched in U1/U5 and U2 snRNPs. The reaction shown in lane 1 was performed in the presence of $3 \mu 1$ of a splicing-competent control extract. Reaction products are indicated at right: (IVS-E2) intron-exon 2 lariat; (IVS) intronlariat; (E1-E2) spliced RNA; (E1) cleaved exon 1. 
A
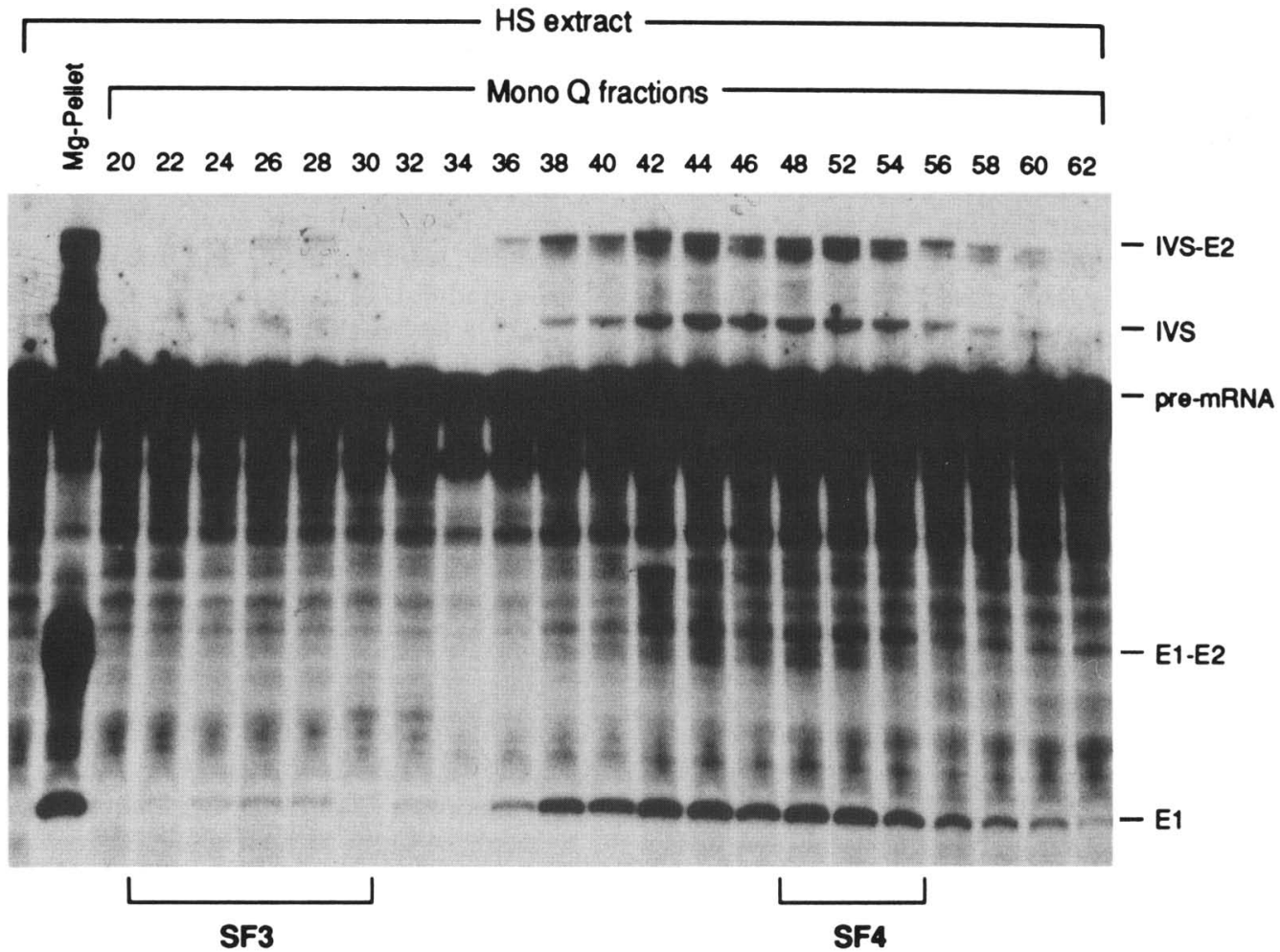

B

$\begin{array}{lllllllllllllllllllll}28 & 30 & 32 & 34 & 36 & 38 & 40 & 42 & 44 & 46 & 48 & 50 & 52 & 54 & 56 & 58 & 60 & 62 & 64 & 66 & 68\end{array}$

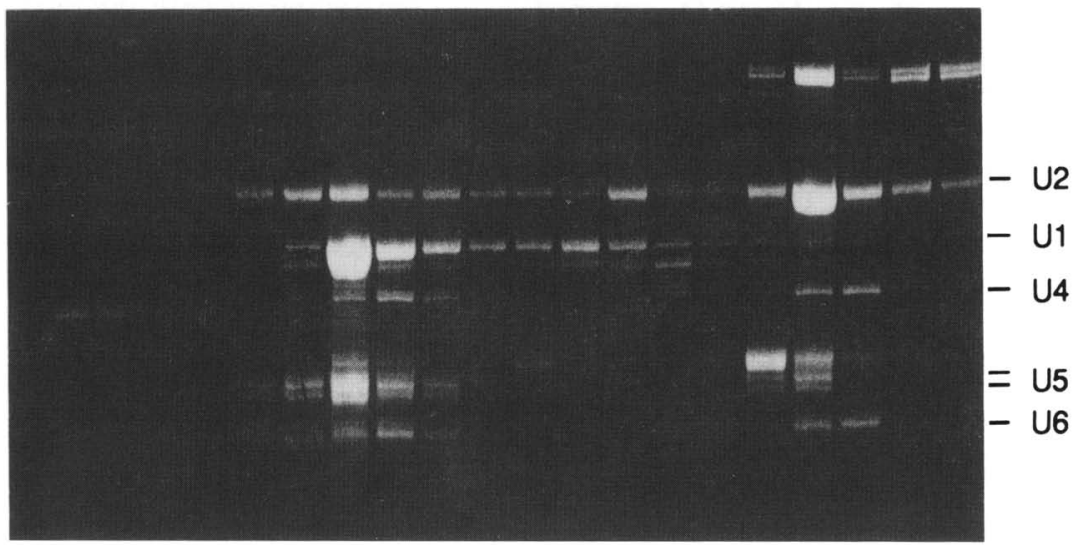

Figure 2. Complementation of heat shock extract with fractions obtained after Mono Q chromatography of the HS500 fraction. (A) Standard splicing reactions were performed in the presence of $3 \mu \mathrm{l}$ of heat shock extract complemented with $2 \mu \mathrm{l}$ of the Mg pellet or consecutive Mono Q fractions as indicated above the lanes. Fractions containing SF3 or SF4 activity are marked below. $(B)$ Analysis of snRNAs present in Mono Q fractions. RNA from $20 \mu \mathrm{l}$ of the Mono Q fractions was isolated, separated in a denaturing $10 \%$ polyacrylamide gel, and stained with ethidium bromide. SnRNAs are indicated at right.

shock extract, suggesting that the complementing activity is different from these factors. Efficient splicing of the substrate RNA is only observed with fractions that contain snRNPs. Both the HS500 fraction and a mixture of Mono $\mathrm{Q}$ fractions enriched in $\mathrm{U} 1$ and $\mathrm{U} 5$ or in $\mathrm{U} 2$
snRNPs restore splicing activity in the heat shock extract.

This result suggested that the complementing activity was either associated with snRNPs or was represented by a new protein factor that was not detected in previous 
assays reconstituted with partially purified splicing activities (Krämer et al. 1987). To distinguish between these possibilities, we tested consecutive Mono $Q$ fractions for rescue of splicing in the heat shock extract. The complementing activity elutes from the Mono Q column in a broad peak between 0.36 and $0.5 \mathrm{M} \mathrm{KCl}$ (Fig. 2A), as evidenced by the appearance of splicing intermediates and products. Although SF4 activity is present in some of these fractions (as indicated in Fig. 2A), the peaks of activity clearly do not coincide. In addition, further purification of SF4 on Blue-Sepharose results in its separation from the complementing activity (see Fig. 1). U1 and U5 snRNPs, as well as one population of U4/U6 snRNP, are present in the active Mono $Q$ fractions (Fig. 2B). However, there is no obvious correlation between the efficiency of splicing in particular fractions and the concentration of any of these particles. Thus, we conclude that the complementing activity /which will be referred to as HSLF for heat shock-labile splicing factor) is distinct from the splicing activities that we have characterized to date.

In an attempt to separate HSLF activity from snRNPs, the most active Mono $Q$ fractions were subjected to Blue-Sepharose chromatography. This chromatographic step results in the removal of most of the contaminating proteins from snRNPs (Krämer 1990). As shown in Figure $3 \mathrm{~A}$, the BS250 and BS500 fractions contain HSLF activity as tested by complementation of the heat shock extract, whereas the bulk of Ul and U5 snRNPs elute in the BS1000 fraction (Fig. 3B). Thus, HSLF is not tightly associated with any of the spliceosomal snRNPs. This is consistent with previous results by Shukla et al. (1990), who isolated the complementing factor from the $\mathrm{Mg}$ pellet and, after chromatography on Mono Q, obtained a snRNP-free fraction that restored splicing activity in the heat shock extract. The idea that HSLF activity resides in a protein is supported by the observation that it is resistant to digestion by micrococcal nuclease (MNase) (Bond 1988; Shukla et al. 1990; U. Utans and A. Krämer, unpubl.); in addition, it is partially sensitive to treatment with $N$-ethylmaleimide and is inactivated after a $10-\mathrm{min}$ incubation at $50^{\circ} \mathrm{C}$ or higher $/ \mathrm{U}$. Utans and $\mathrm{A}$. Krämer, unpubl.).

\section{HSLF functions in triple snRNP formation and spliceosome assembly}

It has been shown previously that exposure of cells to heat shock interferes with the splicing reaction at the level of spliceosome formation (Bond 1988; Shukla et al. 1990). This effect is most likely linked to the apparent absence of the [U4/U6.U5] triple snRNP from heat shock extracts. Because HSLF activity restored splicing in these extracts, we asked whether it functions in the formation of the triple snRNP and consequently in the assembly of splicing complex B. For the analysis of snRNP assemblies, heat shock extract was incubated under splicing conditions without pre-mRNA in the absence or presence of HSLF. The reactions were sedimented through glycerol density gradients, and the snRNA content of individual gradient fractions was determined by Northern blotting with probes complementary to U4, U5, and U6 RNAs (Fig. 4). In a splicing-competent control extract U4, U5, and U6 RNAs cosediment with a peak in fractions 22-24, indicating the position of the [U4/U6.U5] triple snRNP. A sedimentation constant of this complex of $>20 \mathrm{~S}$ is in good agreement with a size of $25 \mathrm{~S}$ determined previously (Konarska and Sharp 1987; Black and Pinto 1989; Bordonné et al. 1990). Furthermore, 20S U5 snRNP, U4/U6 snRNP, and free U6 RNP are separated in the gradient. In contrast, only trace amounts of U4, U5, and U6 RNAs that sediment with $>20$ S can be detected in gradient fractions obtained from the heat shock extract. Most of the U4 and U6 RNAs are present in particles sedimenting between 10 and $20 \mathrm{~S}$, and U5 sediments at $\sim 20 \mathrm{~S}$. When the heat shock extract is incubated in the presence of the solubilized $\mathrm{Mg}$ pellet or the BS500 fraction before sedimentation, formation of the triple snRNP is restored. (Both fractions were treated with MNase before incubation to abolish possible effects of small amounts of residual snRNPs.) Somewhat lower levels of free U6 RNP are seen upon reconstitution with the $\mathrm{Mg}$ pellet but not with the BS500 fraction, which could be caused by a nuclease present in the $\mathrm{Mg}$ pellet (see below). Taken together, these results show that exposure of cells to heat shock disrupts the [U4/U6.U5] triple snRNP or interferes with the de novo formation of this complex under splicing conditions. The integrity of the individual U4/U6 and U5 snRNPs does not appear to be affected, which is evident from the sedimentation of these particles at $\sim 12-15 \mathrm{~S}$ and $20 \mathrm{~S}$, respectively. The fact that U4, U5, and U6 RNAs are detected in the $25 \mathrm{~S}$ region of the gradient when HSLF-containing fractions are combined with the heat shock extract clearly establishes a role for this factor in the formation of the triple snRNP particle.

We then examined the effect of HSLF activity on splicing complex assembly (Fig. 5). In the heat shock extract the pre-mRNA substrate is assembled into presplicing complex A within $5 \mathrm{~min}$ of incubation under splicing conditions. Complex B is detected after $30 \mathrm{~min}$, and splicing complex $\mathrm{C}$ is not formed at all during the 60min incubation period. Also, incubation for up to $2 \mathrm{hr}$ did not result in the appearance of complex $C$, although complex B accumulated to slightly higher concentrations (not shown). Addition of the solubilized $\mathrm{Mg}$ pellet has a marked effect on splicing complex formation: Complex B is now detected after 15 min of incubation, and the active splicing complex $\mathrm{C}$ begins to form after $\sim 30 \mathrm{~min}$. Reactions performed in the presence of the HSLF-containing BS500 fraction gave essentially the same results (not shown). The kinetics of appearance of the splicing complexes are in good agreement with results obtained with splicing-competent HeLa extracts (Frendewey et al. 1987). Moreover, the electrophoretic mobilities of the complexes formed in the heat shock extract were identical to those observed in splicing extracts (not shown). Complex $\mathrm{H}$, which is thought to reflect the interaction of general RNA-binding proteins with the RNA substrate, is almost undetectable in reac- 


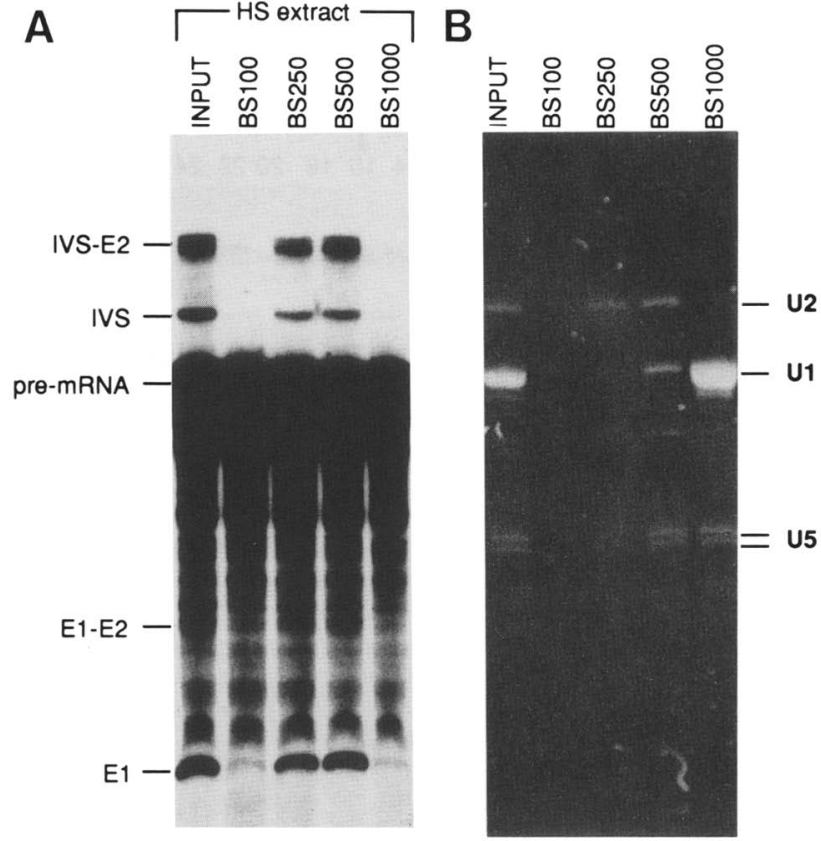

Figure 3. Blue-Sepharose chromatography of Mono $Q$ fractions enriched in HSLF activity and in UI and U5 snRNPs. $(A)$ Heat shock extract was incubated under standard splicing conditions with the Mono $Q$ input fraction or with fractions obtained after Blue-Sepharose chromatography, as indicated above each lane. (B) RNA from $20 \mu \mathrm{l}$ of the input or of the Blue-Sepharose fractions was isolated, separated in a denaturing $10 \%$ polyacrylamide gel, and stained with ethidium bromide.

tions complemented with the solubilized $\mathrm{Mg}$ pellet. This is probably the result of the presence of a nuclease within this fraction and is not observed when the BS500 fraction is used (not shown). However, RNA assembled into the specific complexes $(\mathrm{A}, \mathrm{B}$, and $\mathrm{C})$ appears to be protected from degradation. The reduction in complex A at late stages of spliceosome assembly is presumably not caused by nuclease action but, more likely, results from the conversion of this complex into complexes B and C, consistent with the idea that complex A represents an intermediate in spliceosome formation (Frendewey and Keller 1985; Konarska and Sharp 1986). Notably, this complex accumulates in reactions performed with heat shock extracts where the assembly of splicing complex B is severely reduced.

The results of splicing complex assembly in the absence or presence of HSLF correlate well with those of triple snRNP formation. In the noncomplemented heat shock extract, extremely low concentrations of U4, U5, and U6 RNAs are found to sediment with $>20$ S. This concentration of [U4/U6.U5] triple snRNP appears to be sufficient to allow for the formation of a small amount of complex B, which is, however, not converted into the active spliceosome $C$. Under conditions that promote triple snRNP formation, that is, in the presence of HSLF, the kinetics of B-complex formation are accelerated and splicing complex $\mathrm{C}$ is assembled efficiently.
Comparison of several extracts prepared from heatshocked cells revealed that the inactivation of HSLF occurs in a very narrow temperature range between $43^{\circ} \mathrm{C}$ and $43.5^{\circ} \mathrm{C}$ (not shown). Slight variations from the optimal temperature probably leave low concentrations of HSLF intact, which are sufficient either to protect some triple snRNP complexes from disruption or to allow de novo formation of the triple snRNP under splicing conditions in vitro. Heat shock of cells at slightly higher temperatures $\left(44^{\circ} \mathrm{C}\right)$ resulted in more dramatic effects; splicing activity could not be restored in the presence of HSLF, suggesting that additional splicing components are inactivated. These observations are in agreement with other data showing that the integrity of $U 1$ and $U 2$ snRNPs, as well as the structures of both the nonspecific $\mathrm{H}$-complex and the presplicing complex, are changed after heat shock treatment at $44^{\circ} \mathrm{C}$ (Bond 1988). Also, splicing in extracts prepared from cells heat-shocked at $46^{\circ} \mathrm{C}$ cannot be restored by the addition of the complementing activity (Shukla et al. 1990). Consistent with the efficient assembly of presplicing complexes in heat shock extracts prepared from cells treated at $43.5^{\circ} \mathrm{C}$, structural changes in U1 or U2 snRNPs were not apparent (Shukla ct al. 1990; U. Utans and A. Krämer, unpubl.).

The /U4/U6.U5/ triple snRNP-specific polypeptides restore splicing activity in heat shock extracts

Mammalian spliceosomal snRNPs contain a number of proteins that are common to all particles. Furthermore, several polypeptides have been identified that are specifically associated with U1, U2, or U5 snRNPs (for review, see Lührmann et al. 1990). The protein composition of U4/U6 snRNP is less well established. Although proteins have been described that are found associated with U6 RNA (Grönig et al. 1991) or in the U4/U6 snRNP particle (Okano and Medsger 1991), these proteins are not present in U4/U6 snRNP that has been purified by anti- $m_{3} G$ affinity and Mono $Q$ chromatography (Bach et al. 1989\}. Five proteins $\{$ of $90,60,27,20$, and $15.5 \mathrm{kD}\}$ were, however, detected in the $25 \mathrm{~S}$ [U4/U6.U5] triple snRNP in addition to the common and the U5 snRNPspecific polypeptides (Behrens and Lührmann 1991). Most important, these proteins function in the assembly of the [U4/U6.U5] complex from purified individual U4/ U6 and U5 snRNPs.

That HSLF promotes the formation of the triple snRNP complex in the heat shock extract raised the question whether this activity is equivalent to the [U4/ U6.U5|-specific proteins. To investigate this possibility, the heat shock extract was complemented with isolated 12S U4/U6 and 20S U5 snRNPs (Bach et al. 1989), the purified 25S [U4/U6.U5] snRNP complex (Behrens and Lührmann 1991), or the solubilized triple snRNP-specific proteins that were obtained by MNase digestion of the isolated triple snRNP fraction. The $12 \mathrm{~S} \mathrm{U} 4 / \mathrm{U} 6$, the $20 S$ U5, or a combination of both snRNPs does not restore splicing activity in the heat shock extract (Fig. 6). Splicing of the pre-mRNA substrate is only detected 
Figure 4. Glycerol density gradient sedimentation of snRNP complexes. Splicing reactions containing splicing-competent nuclear extract, heat shock extract, or heat shock extract complemented with MNase-treated $\mathrm{Mg}$ pellet or MNase-treated BS500 were scaled up to $300 \mu \mathrm{l}$ and incubated for $2 \mathrm{hr}$ in the absence of added pre-mRNA substrate. SnRNPs were separated in glycerol gradients as detailed in Materials and methods. In a parallel gradient, 20S U5 snRNP was sedimented as a size marker. RNA was extracted from the input reaction or from every second gradient fraction and analyzed by Northern blotting with radiolabeled antisense U4, U5, and U6 snRNA transcripts as probes. The positions of marker proteins sedimented under identical conditions are indicated at top.

when the 25S [U4/U6.U5] snRNP, either intact or after MNase digestion, is included in the reaction. The effect seen with the triple snRNP-specific proteins is similar to that observed with the Blue-Sepharose-purified HSLF fraction. The fact that splicing in the presence of the triple snRNP or the associated proteins is rather inefficient can be explained by the low concentration of these components in the fraction used or by a partial inactivation during the purification procedure.

In conclusion, our results confirm and extend previous data that an in vivo heat shock impairs splicing by interference with triple snRNP assembly and clearly demonstrate that the integrity of this particle is an essential prerequisite for the splicing reaction. The mere presence of U4/U6 and U5 snRNPs does not suffice either for triple snRNP formation (Behrens and Lührmann 1991) or for the rescue of splicing in the heat shock extract. The fact that either the solubilized triple snRNP proteins or partially purified HSLF allow splicing to proceed suggests that HSLF represents one or more of the proteins that are found only in association with the [U4/U6.U5] snRNP complex.

\section{Discussion}

We have used extracts prepared from heat-shocked HeLa cells as a complementation system to characterize an activity that restores splicing activity in these extracts. This assay system has been used to partially purify the complementing factor (HSLF) and to investigate, in more detail, the cause of the inhibition in splicing after heat shock.

In an attempt to correlate the complementing activity, which was first identified by Shukla et al. (1990) with several splicing factors, we found that none of the protein factors that function in presplicing complex formation (SF1, SF3, or U2AF), B-complex formation (SF2), or assembly of the active spliceosome C (SF4) (Krämer 1988; Ruskin et al. 1988; Zamore and Green 1989; Utans and Krämer 1990; Krämer and Utans 1991; U. Utans and A. Krämer, unpubl.) could restore splicing in the heat shock extract. Instead, the complementing activity was detected in Mono Q fractions containing the spliceosomal snRNPs; subsequent chromatography on Blue-Sepharose separated the activity from these particles. Thus,

\section{Control extract}

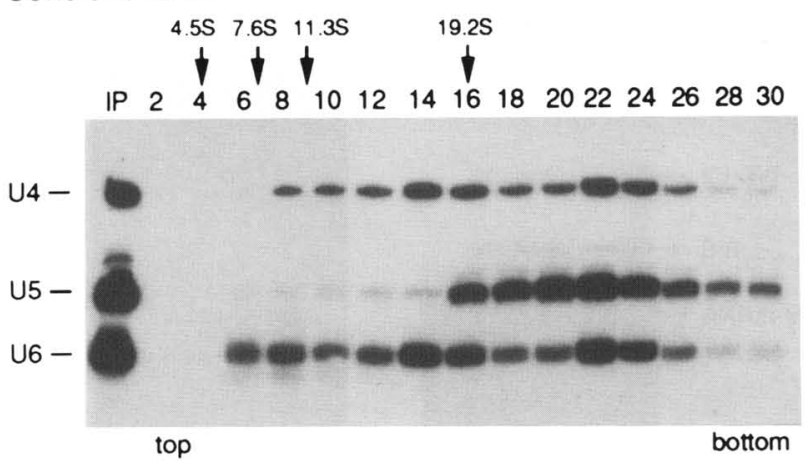

HS extract

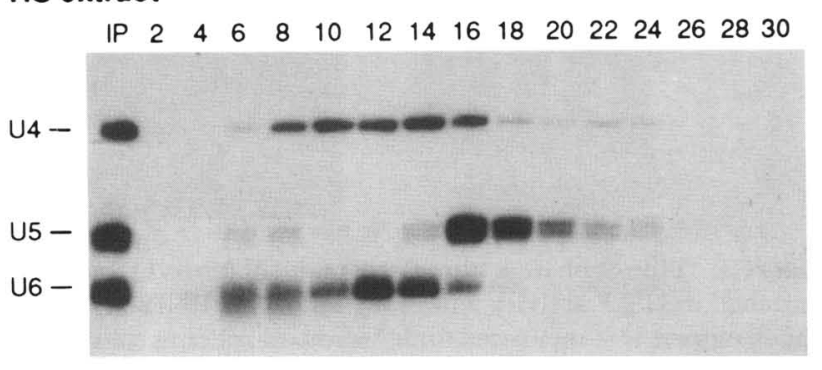

HS extract + Mg-Pellet (MN-treated)

$\begin{array}{llllllllllllllll}\text { IP } & 2 & 4 & 6 & 8 & 10 & 12 & 14 & 16 & 18 & 20 & 22 & 24 & 26 & 28 & 30\end{array}$

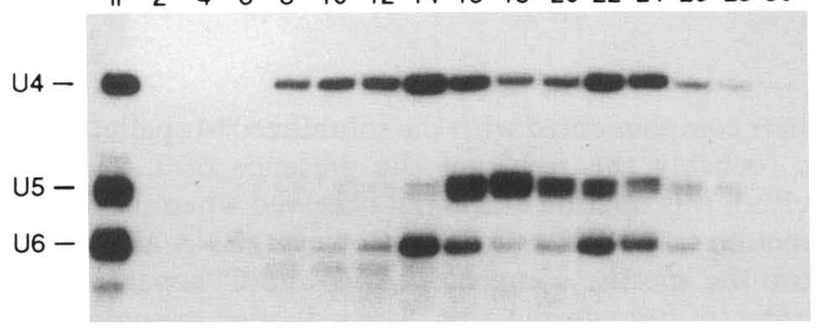

HS extract + BS500 (MN-treated)

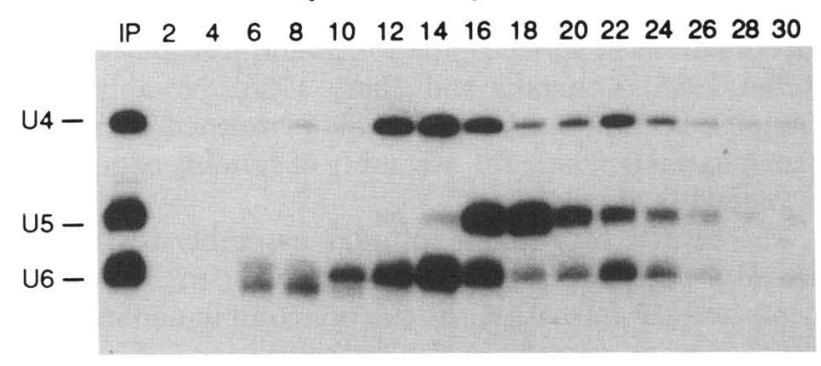

$20 \mathrm{~S}$ U5 SnRNP

$\begin{array}{llllllllllllllll}\text { IP } & 2 & 4 & 6 & 8 & 10 & 12 & 14 & 16 & 18 & 20 & 22 & 24 & 26 & 28 & 30\end{array}$

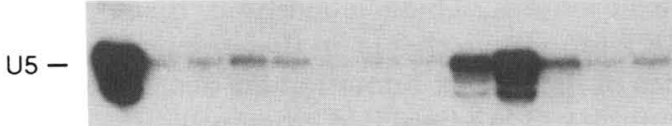




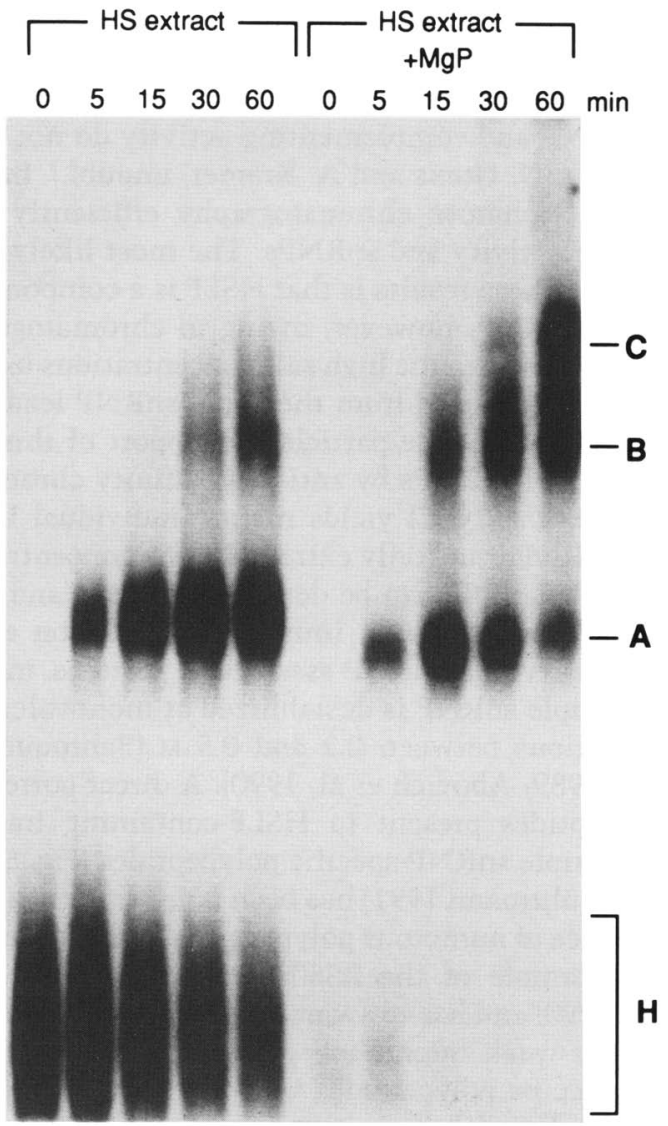

Figure 5. Effect of HSLF on splicing complex formation in heat shock extracts. Heat shock extract was incubated in the absence or in the presence of the $\mathrm{Mg}$ pellet for the indicated times under standard splicing conditions. Reaction products were separated in a nondenaturing $3.75 \%$ polyacrylamide gel. The positions of splicing complexes $\mathrm{A}, \mathrm{B}$, and $\mathrm{C}$ are indicated at right.

HSLF is distinct from the factors mentioned above and is not tightly associated with the spliceosomal snRNPs.

The requirement of HSLF subsequent to presplicing complex formation (see below) also suggests that the activity is different from several other splicing factors shown to function at the onset of spliceosome assembly (Fu and Maniatis 1990; Ge and Manley 1990; Krainer et al. 1990; Ast et al. 1991; Delannoy and Caruthers 1991). Furthermore, HSLF activity appears to be different from a heat-labile activity that functions in the second cleavage-ligation reaction (Krainer and Maniatis 1985), because heat-treated nuclear extracts can complement extracts prepared from heat-shocked cells (Bond 1988; Shukla et al. 1990).

Previous in vitro studies have demonstrated that heat shock interferes with splicing at the level of spliceosome formation, which correlates with the deficiency of heat shock extracts in a triple snRNP complex containing U4, U5, and U6 RNAs (Bond 1988; Shukla et al. 1990). In our heat shock extracts, presplicing complexes accumulate and functional analysis of HSLF activity revealed that the factor is essential for the formation of the triple
snRNP, as well as for the efficient assembly of splicing complex $B$ and its subsequent conversion into the active spliceosome. Thus, HSLF appears to function by promoting the formation of the triple snRNP such that splicing complex formation can proceed. This conclusion is supported by the fact that the addition of the purified [U4/ U6.U5] complex likewise activates splicing in the heat shock extract.

Moreover, we have shown that not only the intact triple snRNP, but also its associated polypeptides, are essential for splicing in the heat shock extract. The requirement for these proteins to overcome the splicing defect correlates in all aspects with the function of the polypeptides in triple snRNP assembly (Behrens and Lührmann 1991). First, combining 12 S U4/U6 and $20 S$ U5 snRNPs does not lead to the formation of the triple snRNP, and their addition to the heat shock extract is insufficient to restore splicing activity. This result was not unexpected as apparently intact U4/U6 and U5 snRNPs are present in sufficient quantities in the heat shock extract. Second, incubation of the individual

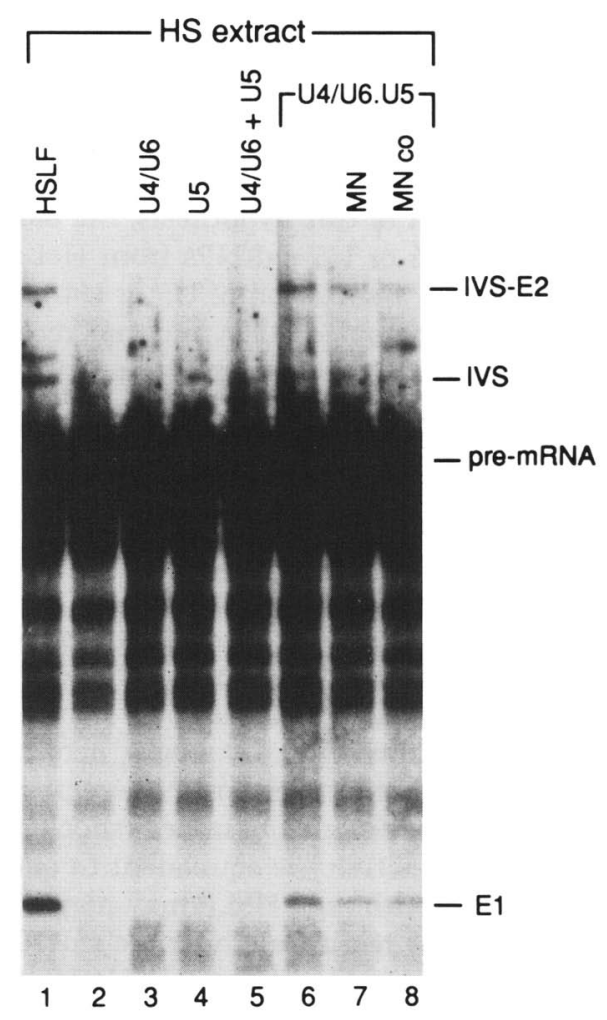

Figure 6. Complementation of heat shock extract with purified snRNPs, triple snRNP-specific proteins, or HSLF. Standard splicing reactions were performed in the presence of $3 \mu \mathrm{l}$ of heat shock extract. The reactions shown in lanes $2-8$ contained the following additions: (Lane 1) $2 \mu \mathrm{l}$ of HSLF (Mono Q); (lane 2) buffer; (lane 3) $2 \mu \mathrm{l}$ of 10S U4/U6 snRNP; (lane 4) $2 \mu \mathrm{l}$ of $20 \mathrm{~S}$ U5 snRNP; (lane 5) $1 \mu$ l of U4/U6 plus $1 \mu$ l of U5 snRNPs; (lane 6) $2 \mu \mathrm{l}$ of $25 \mathrm{~S}$ [U4/U6.U5] triple snRNP. In the reactions shown in lanes 7 and 8, the [U4/U6.U5] fraction was preincubated in the presence or in the absence of MNase, respectively. 
snRNPs with polypeptides isolated from the purified [U4/U6.U5] complex results in the assembly of the triple snRNP. Similarly, these proteins are necessary and sufficient to counteract the inhibition of splicing, conceivably by interacting with endogenous U4/U6 and U5 snRNPs.

To our knowledge, this is the first time that a function for specific snRNP proteins in the mammalian splicing system has been demonstrated. It remains to be shown whether all or only a subset of the triple snRNP-specific proteins are required for the assembly of the particle and whether they might play a more direct role in the splicing process. Another example of a specific snRNP protein for which a function has been documented is the U1 snRNP C protein that potentiates the base-pairing interaction between U1 RNA and the $5^{\prime}$ splice site (Heinrichs et al. 1990). Because these experiments were performed with purified Ul snRNP in the absence of other splicing components, it is not clear whether the $\mathrm{C}$ protein also facilitates U1 snRNP binding during the splicing reaction.

Our results emphasize the role of the triple snRNP during spliceosome assembly by directly demonstrating that the preassembled [U4/U6.U5] complex, but not individual U4/U6 and U5 snRNPs, participate in the splicing reaction. Konarska and Sharp (1987), as well as Cheng and Abelson (1987), detected the triple snRNP in mammalian or yeast splicing extracts and postulated that this snRNP assembly interacts with the presplicing complex. In support of this hypothesis, the biochemical depletion of U4/U6 or U5 snRNPs from HeLa extracts prevents the stable association of U5 or U4/U6 snRNP, respectively, with the pre-mRNA and thus results in the inhibition of splicing complex formation (Barabino et al. 1990; Lamm et al. 1991). Similarly, the genetic depletion of U5 snRNP from yeast cells impairs the binding of U4/U6 snRNP to the pre-mRNA substrate (Seraphin et al. 1991/. Finally, the yeast U5 snRNP-specific protein PRP8, which is also detected in the [U4/U6.U5] complex of yeast and becomes incorporated into the spliceosome (Lossky et al. 1987; Whittaker et al. 1990), is required for the formation of the active splicing complex; in its absence, complexes accumulate that only contain Ul and U2 snRNAs (J.D. Brown and J.D. Beggs, pers. comm.).

As both HSLF and the triple snRNP-specific polypeptides are able to rescue splicing in heat shock extracts it appears that HSLF activity is equivalent to one or more of these proteins. Although HSLF may play an indirect role, for example, by recruiting the triple snRNP-specific polypeptides for assembly of the [U4/U6.U5] complex, we favor the hypothesis that HSLF is an integral component of the triple snRNP. HSLF activity coelutes from a Mono Q column with the majority of Ul and U5 snRNPs and at least one population of U4/U6 snRNP. Analysis of snRNP assemblies in these fractions revealed that part of U4/U6 and U5 snRNPs are present as a triple snRNP. In contrast, U4 and U6 RNAs that coelute from Mono Q with U2 snRNP at higher salt concentrations sediment in glycerol gradients with $\sim 12 \mathrm{~S}$ (U. Utans and A. Krämer, unpubl.), and no complementing activity can be detected in these fractions. Although the presence of the triple snRNP in some of the early-eluting Mono Q fractions may be responsible, in part, for rescue of splicing, triple snRNP and complementing activity do not correlate strictly (U. Utans and A. Krämer, unpubl.). In addition, Blue-Sepharose chromatography efficiently separates HSLF activity and snRNPs. The most likely interpretation of these results is that HSLF is a component of the triple snRNP; however, owing to chromatographic manipulations (e.g., the high salt concentrations used for elution) it is removed from the triple snRNP leading to the dissociation of the particle. In support of this idea, purification of snRNPs by anti- $\mathrm{m}_{3} \mathrm{G}$ affinity chromatography at $0.42 \mathrm{M} \mathrm{NaCl}$ yields mainly individual U4/U6 and U5 snRNPs, and only extremely low concentrations of the triple snRNP can be detected (Behrens and Lührmann 1991|. In addition, immunoprecipitation experiments with yeast snRNP-associated proteins indicate that the triple snRNP is destabilized at monovalent salt concentrations between 0.2 and $0.5 \mathrm{M}$ (Banroques and Abelson 1989; Abovich et al. 1990). A direct correlation of polypeptides present in HSLF-containing fractions with the triple snRNP-specific polypeptides (Fig. 5; Behrens and Lührmann 1991) has been hampered thus far by the presence of numerous polypeptides in these fractions (for an example of the BS500 fraction, see Fig. 3 in Krämer 1990) and has to await further purification steps.

A rather weak interaction of HSLF and/or the triple snRNP-specific polypeptides with the [U4/U6.U5] complex correlates with the notion that the spliceosome represents a dynamic structure allowing for conformational changes during spliceosome maturation, such as the destabilization of the U4/U6 base-pairing interaction that takes place during the activation of the splicing complex (Pikielny et al. 1986; Cheng and Abelson 1987; Konarska and Sharp 1987; Lamond et al. 1988; Blencowe et al. 1989|. It will be interesting to see whether all of the triple snRNP-specific polypeptides are incorporated into the spliceosome and, if so, whether they stay associated with the complex during the entire splicing reaction. Furthermore, it remains to be determined whether a (perhaps modified) form of the triple snRNP persists after the destabilization of the U4/U6 interaction or whether the particle dissociates into its individual components within the active spliceosome.

How can we reconcile our data with the events that occur during the heat shock response in vivo? As shown by Yost and Lindquist (1988), splicing is inhibited in Drosophila cells before 5' cleavage and lariat formation, consistent with the in vitro results presented here and by others (Bond 1988; Shukla et al. 1990). Our data suggest that the disruption of the triple snRNP is the first consequence of heat shock in the splicing reaction, whereas at higher temperatures other splicing components are also inactivated. Triple snRNP formation appears to be a conserved feature in being a prerequisite for spliceosome formation in both yeast and mammalian splicing systems (Cheng and Abelson 1987; Konarska and Sharp 1987). Hence, an inhibition at this step of the splicing reaction probably ensures that none of the intron-con- 
taining pre-mRNAs undergo splicing complex formation, whereas the intronless hsp transcripts remain unaffected.

When a mild heat shock is administered to cells before a more severe heat shock, a disruption of splicing is not observed in vivo or in vitro (Yost and Lindquist 1986, 1991 and references therein; Bond 1988). As discussed by these investigators, it is highly likely that hsps, which are induced during mild heat shock, function in the protection of the splicing apparatus. The proposed role for hsps in the folding-unfolding or disaggregation of protein complexes (Pelham 1990) makes these proteins good candidates for interacting with the triple snRNP complex or its protein components, thus preventing the disassembly of the particle. The availability of an in vitro system that reproduces the in vivo situation should facilitate further analysis of the heat shock response.

\section{Materials and methods}

Preparation of heat shock extracts

HeLa cells $\left(5 \times 10^{5}\right)$ were incubated in $500 \mathrm{ml}$ of medium $/ \mathrm{Her}$ nandez and Keller 1983 ) at $43.5^{\circ} \mathrm{C}$ for $2 \mathrm{hr}$, and extracts were prepared as described by Shukla et al. (1990).

\section{Fractionation of splicing activities}

The Mg pellet was prepared from HeLa splicing extracts according to Shukla et al. (1990).

Chromatography of splicing-competent HeLa cell nuclear extracts was as described previously (Krämer et al. 1987; Krämer and Keller 1990; Krämer and Utans 1991). SF4 activity was purified further from Mono Q fractions by chromatography on Blue-Sepharose (Pharmacia). The sample was applied in a buffer containing $10 \%$ glycerol, $20 \mathrm{~mm}$ HEPES-KOH $(\mathrm{pH} 7.9), 0.1 \mathrm{M}$ $\mathrm{KCl}, 3 \mathrm{mM} \mathrm{MgCl}, 0.1 \mathrm{~mm}$ EDTA, and $0.5 \mathrm{~mm}$ dithiothreitol (DTT). The column was washed with the same buffer, and bound proteins were eluted with a linear gradient of $0.1-1.5 \mathrm{M}$ $\mathrm{KCl}$ in the same buffer. SF4 activity eluted between 0.5 and 0.9 $\mathrm{M} \mathrm{KCl}$.

Mono Q fractions enriched in $\mathrm{U} 1$ and $\mathrm{U} 5$ snRNPs and in HSLF activity were further fractionated on Blue-Sepharose as described (Krämer 1990). Bound components were eluted with $0.25,0.5$, and $1.0 \mathrm{M} \mathrm{KCl}$.

\section{Isolation of snRNP particles}

U4/U6 snRNP (12S), U5 snRNP (20S), and 25S (U4/U6.U5) triple snRNP were purified as described by Behrens and Lührmann (1991) and dialyzed against a buffer containing $20 \%$ glycerol, 20 mM HEPES-KOH (pH 7.9), $3 \mathrm{~mm} \mathrm{MgCl}_{2}, 0.1 \mathrm{~mm}$ EDTA, and 0.5 $\mathrm{mM}$ DTT. The protein concentrations of the samples were as follows: $12 \mathrm{~S}$ U4/U6 snRNP, $90 \mu \mathrm{g} / \mathrm{ml}$; 20S U5 snRNP, $150 \mu \mathrm{g} /$ $\mathrm{ml}$; triple snRNP, $70 \mu \mathrm{g} / \mathrm{ml}$.

The triple snRNP was digested with $1000 \mathrm{U} / \mathrm{ml}$ of $\mathrm{MNase}$ (Pharmacia) for $15 \mathrm{~min}$ at $30^{\circ} \mathrm{C}$ in the presence of $1 \mathrm{mM} \mathrm{CaCl}_{2}$. The reaction was stopped by the addition of $2 \mathrm{~mm}$ EGTA.

In vitro transcription of splicing substrates and antisense probes

Pre-mRNA was prepared by in vitro transcription with SP6 RNA polymerase (Krämer 1988). The resulting RNA is derived from the adenovirus 2 major late transcription unit and contains the $5^{\prime}$ and $3^{\prime}$ splice sites of the first intron (RNA1; Frendewey and Keller 1985).

Antisense probes for Northern blot hybridization were generated as follows: DNA pSP65/U4b or pSP65/U5b /a gift from D. Black and J. Steitz) was linearized with HindIII or XbaI, respectively, and transcribed with SP6 RNA polymerase. Gemini plasmid DNA containing U6 gene sequences (Hamm et al. 1989; a gift from A. Lamond) was cleaved with PstI and transcribed with T7 RNA polymerase for $30 \mathrm{~min}$ at $37^{\circ} \mathrm{C}$. Reactions were carried out in the absence of cap analog and unlabeled UTP; instead, 0.5 mM GTP and $40 \mu \mathrm{Ci}\left[\alpha^{-32}\right.$ P $]$ UTP $(800 \mathrm{Ci} / \mathrm{mmole}$; Amersham $\mid$ were added. After phenol-chloroform extraction and ethanol precipitation, the transcripts were used directly for hybridization.

\section{In vitro splicing reactions}

Splicing reactions $(10 \mu$ l final volume) contained $3 \mu$ l of heat shock extract and $2 \mu \mathrm{l}$ of the components indicated in the figure legends. Reaction conditions were as described (Utans and Krämer 1990|. For the analysis of splicing complexes, reactions were terminated by the addition of heparin to a final concentration of $200 \mu \mathrm{g} / \mathrm{ml}$. The reactions were loaded onto $3.75 \%$ polyacrylamide gels (acrylamide/bisacrylamide $80: 1$ ) in $25 \mathrm{~mm}$ Tris, $25 \mathrm{~mm}$ boric acid, and $1 \mathrm{~mm}$ EDTA. Electrophoresis was for $5 \mathrm{hr}$ at $4 \mathrm{~W}$.

\section{Sedimentation of snRNPs in glycerol gradients}

Splicing reactions (in the absence of exogenous pre-mRNA) were scaled up to a total volume of $300 \mu \mathrm{l}$ and incubated for 2 $\mathrm{hr}$ at $30^{\circ} \mathrm{C}$. The samples were layered onto $13-\mathrm{ml} 15-40 \%$ / $\mathrm{vol} /$ vol) glycerol gradients in $20 \mathrm{mM}$ HEPES-KOH $(\mathrm{pH} 7.9), 0.1 \mathrm{M}$ $\mathrm{KCl}, 3 \mathrm{mM} \mathrm{MgCl}$, and $0.1 \mathrm{mM}$ EDTA. After sedimentation at $39,000 \mathrm{rpm}$ for $20 \mathrm{hr}$ in a TST41.14 rotor (Kontron) at $4^{\circ} \mathrm{C}$, fractions of $400 \mu \mathrm{l}$ were harvested from top to bottom. Marker proteins (thyroglobulin, 19.3S; catalase, 11.3S; yeast alcohol dehydrogenase, $7.6 \mathrm{~S}$; bovine serum albumin, $4.5 \mathrm{~S}$ ) were sedimented in parallel gradients. Their positions were localized by measurement of the absorbance at $280 \mathrm{~nm}$.

\section{Northern blot analysis of SnRNAs}

Three microliters of the glycerol gradient input or $100 \mu \mathrm{l}$ of individual gradient fractions was digested with proteinase $\mathrm{K}_{\text {; }}$ the RNAs were ethanol-precipitated and separated in a $10 \%$ polyacrylamide $/ 8.3 \mathrm{M}$ urea gel. The gel was soaked twice for 30 min in $1 \mathrm{~m}$ Tris $/ 50 \mathrm{~mm}$ EDTA/0.5 $\mathrm{M}$ sodium acetate $(\mathrm{pH} 7.8)$, and the RNA was transferred onto a GeneScreen membrane (Schleicher \& Schüll) with a semidry blotting apparatus in the above buffer for $1 \mathrm{hr}$ at $150 \mathrm{~mA}$. The membrane was UV-irradiated with $2000 \mu \mathrm{W} / \mathrm{cm}^{2}$ for $75 \mathrm{sec}$ and baked for $30 \mathrm{~min}$ at $80^{\circ} \mathrm{C}$. After prehybridization for $2-3 \mathrm{hr}$ in hybridization buffer $150 \%$ formamide, $5 \times$ SSC, $5 \times$ Denhardt's solution, $1 \%$ SDS, $25 \%$ (wt/vol) dextrane sulfate, $50 \mathrm{mM} \mathrm{NaPO}_{4}(\mathrm{pH} 6.5), 0.1 \mathrm{mg} /$ $\mathrm{ml}$ of herring sperm DNA] antisense U4, U5, and U6 transcripts $\left(2 \times 10^{6}\right.$ Cerenkov cpm each) were added and hybridized to the filters for $12-16 \mathrm{hr}$ at $42^{\circ} \mathrm{C}$. Filters were washed twice for $30 \mathrm{~min}$ in $1 \times \mathrm{SSC} / 0.1 \% \mathrm{SDS}$, twice for $30 \mathrm{~min}$ in $0.5 \times \mathrm{SSC} / 0.1 \% \mathrm{SDS}$, and exposed to X-ray film.

\section{Acknowledgments}

We thank D. Black, J. Steitz, and A. Lamond for providing plasmids encoding antisense RNAs, A. Bürer for cell culture, W. 
Keller for support, and W. Keller and G. Bilbe for helpful comments on the manuscript. This work was supported by grants from the Schweizer Nationalfonds and the Kantons of BaselStadt and Basel-Landschaft to A.K. and W. Keller, from the Deutsche Forschungsgemeinschaft (SFB 272) to R.L., and from the National Institute of Health to R.K.

The publication costs of this article were defrayed in part by payment of page charges. This article must therefore be hereby marked "advertisement" in accordance with 18 USC section 1734 solely to indicate this fact.

\section{References}

Abovich, N., P. Legrain, and M. Rosbash. 1990. The yeast PRP6 gene encodes a U4/U6 small nuclear ribonucleoprotein particle (snRNP) protein, and the PRP9 gene encodes a protein required for U2 snRNP binding. Mol. Cell. Biol. 10: 64176425.

Ast, G., D. Goldblatt, D. Offen, J. Sperling, and R. Sperling. 1991. A novel splicing factor is an integral component of 200S large nuclear ribonucleoprotein (lnRNP) particles. $E M B O$ /. 10: 425-432.

Bach, M., G. Winkelmann, and R. Lührmann. 1989. 20 S small nuclear ribonucleoprotein U5 shows a surprisingly complex protein composition. Proc. Natl. Acad. Sci. 86: 6038-6042.

Banroques, J. and J.N. Abelson. 1989. PRP4: A protein of the yeast U4/U6 small nuclear ribonucleoprotein particle. Mol. Cell. Biol. 9: 3710-3719.

Barabino, S.M.L., B.J. Blencowe, U. Ryder, B.S. Sproat, and A.I. Lamond. 1990. Targeted snRNP depletion reveals an additional role for mammalian U1 snRNP in spliceosome assembly. Cell 63: 293-302.

Behrens, S.-E and R. Lührmann. 1991. Immunoaffinity purification of a [U4/U6.U5] tri-snRNP from human cells. Genes \& Dev. 5: 1439-1452.

Bindereif, A. and M.R. Green. 1987. An ordered pathway of snRNP binding during mammalian pre-mRNA splicing complex assembly. EMBO f. 6: 2415-2424.

Black, D.L. and A.L. Pinto. 1989. U5 small nuclear ribonucleoprotein: RNA structure analysis and ATP-dependent interaction with U4/U6. Mol. Cell. Biol. 9: 3350-3359.

Blencowe, B.J., B.S. Sproat, U. Ryder, S. Barabino, and A.I. Lamond. 1989. Antisense probing of the human U4/U6 snRNP with biotinylated 2'-OMe RNA oligonucleotides. Cell 59: 531-539.

Bond, U. 1988. Heat shock but not other stress inducers leads to the disruption of a sub-set of snRNPs and inhibition of in vitro splicing in HeLa cells. EMBO $/$. 7: 3509-3518.

Bordonné, R., J. Banroques, J. Abelson, and C. Guthrie. 1990. Domains of yeast U4 spliceosomal RNA required for PRP4 protein binding, snRNP-snRNP interactions, and premRNA splicing in vivo. Genes \& Dev. 4: 1185-1196.

Cheng, S.-C. and J. Abelson. 1987. Spliceosome assembly in yeast. Genes \& Dev. 1: 1014-1027.

Delannoy, P. and M.H. Caruthers. 1991. Detection and characterization of a factor which rescues spliceosome assembly from a heat-inactivated HeLa cell nuclear extract. Mol. Cell. Biol. 11: 3425-3431.

Frendewey, D. and W. Keller. 1985. Stepwise assembly of a premRNA splicing complex requires U-snRNPs and specific intron sequences. Cell 42: 355-367.

Frendewey, D., A. Krämer, and W. Keller. 1987. Different small nuclear ribonucleoprotein particles are involved in different steps of splicing complex formation. Cold Spring Harbor Symp. Quant. Biol. 52: 287-298.

Fu, X.-D. and T. Maniatis. 1990. Factor required for mammalian spliceosome assembly is localized to discrete regions in the nucleus. Nature 343: 437-441.

Ge, H. and J.L. Manley. 1990. A protein factor, ASF, controls cell-specific alternative splicing of SV40 early pre-mRNA in vitro. Cell 62: 25-34.

Green, M.R. 1991. Biochemical mechanisms of constitutive and regulated pre-mRNA splicing. Annu. Rev. Cell Biol. 7: 559599.

Grönig, K., Z. Palfi, S. Gupta, M. Cross, T. Wolff, and A. Bindereif. 1991. A new U6 small nuclear ribonucleoprotein-specific protein conserved between cis- and trans-splicing systems. Mol. Cell. Biol. 11: 2026-2034.

Guthrie, C. 1991. Messenger RNA splicing in yeast: Clues to why the spliceosome is a ribonucleoprotein. Science 253: 157-163.

Hamm, J., N. Dathan, and I.W. Mattaj. 1989. Functional analysis of mutant Xenopus U2 snRNAs. Cell 59: 159-169.

Heinrichs, V., M. Bach, G. Winkelmann, and R. Lührmann. 1990. Ul-specific protein C needed for efficient complex formation of U1 snRNP with a 5' splice site. Science 247: 69-72.

Hernandez, N. and W. Keller. 1983. Splicing of in vitro synthesized messenger RNA precursors in HeLa cell extracts. Cell 35: 89-99.

Konarska, M.M. and P.A. Sharp. 1986. Electrophoretic separation of complexes involved in the splicing of precursors to mRNAs. Cell 46: 845-855.

- 1987. Interactions between small nuclear ribonucleoprotein particles in formation of spliceosomes. Cell 49: 763-774.

Krainer, A.R. and T. Maniatis. 1985. Multiple factors including small nuclear ribonucleoproteins $U 1$ and $U 2$ are necessary for pre-mRNA splicing in vitro. Cell 42: 725-736.

Krainer, A.R., G.C. Conway, and D. Kozak. 1990. Purification and characterization of pre-mRNA splicing factor SF2 from HeLa cells. Genes \& Dev. 4: 1158-1171.

Krämer, A. 1988. Presplicing complex formation requires two proteins and U2 snRNP. Genes \& Dev. 2: 1155-1167.

- 1990. Purification of small nuclear ribonucleoprotein particles active in RNA processing. Methods Enzymol. 181: 215-232.

Krämer, A. and W. Keller. 1990. Preparation and fractionation of mammalian extracts active in pre-mRNA splicing. Methods Enzymol. 181: 3-19.

Krämer, A. and U. Utans. 1991. Three protein factors (SF1, SF3 and $U 2 A F$ function in presplicing complex formation in addition to snRNPs. EMBO J. 10: 1503-1509.

Krämer, A., M. Frick, W. and Keller. 1987. Separation of multiple components of HeLa cell nuclear extracts required for pre-messenger RNA splicing. I. Biol. Chem. 262: 1763017640.

Lamm, G.M., B.J. Blencowe, B.S. Sproat, A.M. Iribarren, U. Ryder, and A.I. Lamond. 1991. Antisense probes containing 2-aminoadenosine allow efficient depletion of U5 snRNP from HeLa splicing extracts. Nucleic Acids Res. 19: 31933198.

Lamond, A.I., M.M. Konarska, P.J. Grabowski, and P.A. Sharp. 1988. Spliceosome assembly involves the binding and release of U4 small nuclear ribonucleoprotein. Proc. Natl. Acad. Sci. 85: 411-415.

Lossky, M., G.J. Anderson, S.P. Jackson, and J. Beggs. 1987. Identification of a yeast snRNP protein and detection of snRNPsnRNP interactions. Cell 51: 1019-1026.

Lührmann, R., B. Kastner, and M. Bach. 1990. Structure of spliceosomal snRNPs and their role in pre-mRNA splicing. Biochem. Biophys. Acta 1087: 265-292. 
Morimoto, R.I., A. Tissières, and C. Georgopoulos, eds. 1990. Stress proteins in biology and medicine. Cold Spring Harbor Laboratory Press, Cold Spring Harbor, New York.

Okano, Y. and T.A. Medsger. 1991. Newly identified U4/U6 snRNP-binding proteins by serum autoantibodies from a patient with systemic sclerosis. J. Immunol. 146: 535-542.

Pelham, H.R.B. 1990. Functions of the hsp70 protein family: An overview. In Stress proteins in biology and medicine, led. R.I. Morimoto, A. Tissières, and C. Georgopoulos|, pp. $287-$ 299. Cold Spring Harbor Laboratory Press, Cold Spring Harbor, New York.

Pikielny, C.W., B.C. Rymond, and M. Rosbash. 1986. Electrophoresis of ribonucleoproteins reveals an ordered assembly pathway of yeast splicing complexes. Nature 324: 341-345.

Ruskin, B., P.D. Zamore, and M.R. Green. 1988. A factor, U2AF, is required for U2 snRNP binding and splicing complex assembly. Cell 52: 207-219.

Seraphin, B., N. Abovich, and M. Rosbash. 1991. Genetic depletion indicates a late role for U5 snRNP during in vitro spliceosome assembly. Nucleic Acids Res. 19: 3857-3860.

Shukla, R.R., Z. Dominski, T. Zwierzynski, and R. Kole. 1990. Inactivation of splicing factors in HeLa cells subjected to heat shock. J. Biol. Chem. 265: 20377-20383.

Utans, U. and A. Krämer. 1990. Splicing factor SF4 is dispensable for the assembly of a functional splicing complex and participates in the subsequent steps of the splicing reaction. EMBO 1. 9: 4119-4126.

Whittaker, E., M. Lossky, and J.D. Beggs. 1990. Affinity purification of spliceosomes reveals that the precursor RNA processing protein PRP8, a protein in the U5 small nuclear ribonucleoprotein particle, is a component of yeast spliceosomes. Proc. Natl. Acad. Sci. 87: 2216-2219.

Yost, H.J. and S. Lindquist. 1986. RNA splicing is interrupted by heat shock and is rescued by heat shock protein synthesis. Cell 45: 185-193.

1988. Translation of unspliced transcripts after heat shock. Science 242: 1544-1548.

1991. Heat shock proteins affect RNA processing during the heat shock response of Saccharomyces cerevisiae. Mol. Cell. Biol. 11: 1062-1068.

Zamore, P.D. and M.R. Green. 1989. Identification, purification, and biochemical characterization of $\mathrm{U}_{2}$ small nuclear ribonucleoprotein auxiliary factor. Proc. Natl. Acad. Sci. 86: 9243-9247. 


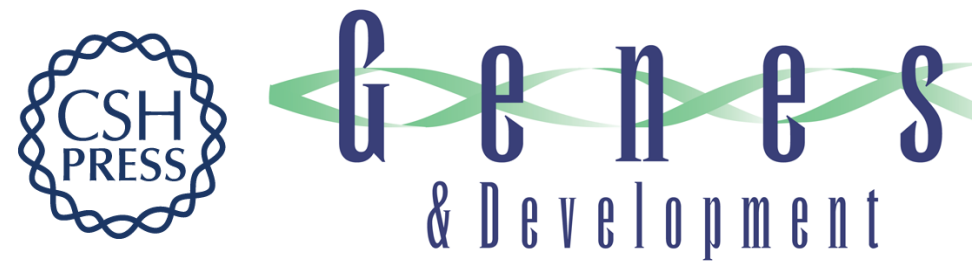

\section{A splicing factor that is inactivated during in vivo heat shock is functionally equivalent to the [U4/U6.U5] triple snRNP-specific proteins.}

U Utans, S E Behrens, R Lührmann, et al.

Genes Dev. 1992, 6:

Access the most recent version at doi:10.1101/gad.6.4.631

References This article cites 47 articles, 22 of which can be accessed free at: http://genesdev.cshlp.org/content/6/4/631.full.html\#ref-list-1

License

Email Alerting Receive free email alerts when new articles cite this article - sign up in the box at the top Service right corner of the article or click here.

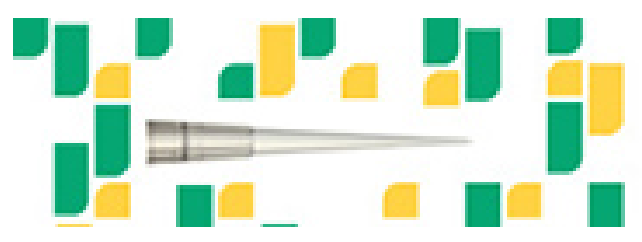

Focused on your science. 